\title{
International Law and the Death Penalty
}

\author{
A Toothless Tiger, or a Meaningful Force for Change?
}

\author{
SANDRA L. BABCOCK
}

\section{INTRODUCTION}

Over the last several decades, the world has made great strides towards universal abolition of the death penalty. Since the Universal Declaration on Human Rights was adopted in 1948, nearly 100 countries have abolished the death penalty as a matter of law. European and Latin American nations have been on the forefront of abolitionist efforts, but anti-death-penalty sentiment is not limited to those regions; support for the death penalty is waning in Africa and Southeast Asia as well. All but one or two nations claim to no longer execute minors, and many of the world's leading executioners have greatly reduced the number of crimes for which the death penalty can be applied. The General Assembly of the United Nations has now passed four resolutions in favor of a universal moratorium on capital punishment, and each has been supported by a greater number of countries-even those that were previously considered staunch supporters of the death penalty. ${ }^{1}$

The international abolitionist community has celebrated each of these markers of progress. The city of Rome, Italy, lights up its ancient coliseum for each country that abolishes the death penalty. Many commentators have claimed that it is just a matter of time before the death penalty fades away entirely. Professor Schabas has likened the remaining strongholds of capital punishment to the greying piles of late-winter 
snow in his native Canada, once so imposing, but now slowly-and inevitablymelting into oblivion.

But despite these encouraging prognoses, the death penalty remains rooted in a significant number of states. Even in countries that have abstained from carrying out executions under an unofficial moratorium of sorts, courts continue to sentence individuals to death. According to Amnesty International, there are at least 19,000 men and women on death rows around the world. ${ }^{2}$ Many of them will eventually be executed after trials that are far from meeting international fair trial standards. Moreover, the pace of abolition seems to have slowed worldwide. According to Amnesty International, fourteen countries abolished the death penalty in the 1980s, thirty-four in the 1990s, and twenty-four in the 2000s. ${ }^{3}$ Yet in the first five years of this decade, only five countries have done so. ${ }^{4}$

International human rights organizations and abolitionist states have relied on two principal strategies to promote abolition: political pressure and law reform. The European Union has made the death penalty a key pillar of its human rights agenda, and has been instrumental in bringing about abolition of capital punishment in a number of states. A coalition of abolitionist (mainly European) states backed the initial moratorium resolution in the General Assembly in 2007, and every two years they engage in intensive lobbying efforts to persuade states to join the abolitionist fold. European diplomats meet with foreign leaders and issue public statements supporting abolition. ${ }^{5}$ International non-governmental organizations have played key supporting roles in these efforts: Hands Off Cain, an Italian abolitionist organization, has sponsored a series of meetings with African leaders in states that are teetering on the brink of abolition. ${ }^{6}$

International non-governmental organizations and individual lawyers have been equally active in challenging the application of the death penalty through litigation

2. Amnesty International, 'Death Sentences and Executions 2014' (2015) www.amnestyusa.org/ pdfs/DeathSentencesAndExecutions2014_EN.pdf3 (last accessed 14 December 2015).

3. Amnesty International, 'Abolitionist and Retentionist Countries', www.amnesty.org/en/deathpenalty/abolitionist-and-retentionist-countries (last accessed 16 February 2015). It should be noted that some of the countries that abolished the death penalty for all crimes during the 1990s and 2000s, such as Canada, Italy, Mexico, and the United Kingdom, were already, in practice, abolitionist.

4. Those countries are Gabon, Madagascar, Mongolia, the Republic of Congo, and Suriname. Ibid (n 3); see also Delphine Lourtau, 'Mongolia Becomes the Fifth Country to Abolish the Death Penalty in 2015' (Death Penalty Worldwide, 14 December 2015), http://blog.deathpenaltyworldwide.org/2015/12/mongolia-becomes-the-fifth-country-to-abolish-the-death-penalty-in-2015. html (last accessed 14 December 2015). Latvia, Fiji, and Bolivia recently abolished the death penalty for all crimes, but all had already abolished the death penalty for so-called 'ordinary' crimes. They cannot therefore be considered 'new' abolitionist countries.

5. See eg Michael Nevin, 'Death Penalty: Will Malawi Join the Modern World in Abolishing It?' (Nyasa Times, 21 January 2015), www.nyasatimes.com/2015/01/21/death-penalty-will-malawijoin-the-modern-world-in-abolishing-it/ (last accessed 16 February 2015).

6. See Hands Off Cain, 'West African Governments and Civil Society Discuss Death Penalty in Freetown', www.worldcoalition.org/wast-africa-sierra-leone-hands-off-cain-fiacat.html (last accessed 16 January 2014). 
and law reform. Over time, these efforts have brought about outright abolition in some states (such as South Africa), and critical reforms in others.

This chapter examines the potential of international law to promote abolition and the challenges that prevent the full realization of that potential. In Section II, the chapter provides a brief overview of how international norms relating to the application of the death penalty have evolved over time. Section III provides three examples of how their impact has been limited in practice. Section IV suggests a number of prescriptive measures to address these limitations.

\section{THE PROMISE OF INTERNATIONAL LAW}

International law is often touted as a key influence in the abolition of the death penalty. Both international and regional human rights treaties set forth limitations on the application of the death penalty. These treaty provisions have since been supplemented by norms of customary international law that have evolved over time, supported by state practice and the judgments of international tribunals, national courts, and the writings of jurists and scholars. It is beyond the scope of this chapter to provide an exhaustive listing of these developments, and in any event the reader would be better served by referring to Professor Schabas's seminal treatise and multiple articles on the topic. ${ }^{7}$ Nevertheless, a brief overview of the applicable international instruments is in order.

Article 6 of the International Covenant on Civil and Political Rights (ICCPR), adopted in $1966,{ }^{8}$ imposes certain limits on the application of the death penalty, notably:

1. Every human being has the inherent right to life. This right shall be protected by law. No one shall be arbitrarily deprived of his life.

2. In countries which have not abolished the death penalty, sentence of death may be imposed only for the most serious crimes in accordance with the law in force at the time of the commission of the crime and not contrary to the provisions of the present Covenant and to the Convention on the Prevention and Punishment of the Crime of Genocide. This penalty can only be carried out pursuant to a final judgement rendered by a competent court.

$\ldots$

7. William Schabas, The Abolition of the Death Penalty under International Law (first published 1993, 3rd edn (Cambridge: Cambridge University Press 2002); William Schabas, 'International Law, Politics, Diplomacy and the Abolition of the Death Penalty' (2004) 13(2) William and Mary Bill of Rights J 417; William Schabas and Gerard Cohen Jonathan (eds), La peine capitale et le droit international des droits de l'homme (2003); William Schabas, The Death Penalty as Cruel Treatment and Torture: Capital Punishment Challenged in the World's Courts (1996); William Schabas, 'Soering's Legacy: The Human Rights Committee and the Judicial Committee of the Privy Council Take a Walk Down Death Row' (1994) 43(4) ICLQ 913; William Schabas, 'International Norms on Execution of the Insane and the Mentally Retarded' (1993) 4(1) Criminal L Forum 95.

8. International Covenant on Civil and Political Rights (adopted 16 December 1966, entered into force 23 March 1976) 999 UNTS 171 [hereinafter ICCPR]. 
4. Anyone sentenced to death shall have the right to seek pardon or commutation of the sentence. Amnesty, pardon or commutation of the sentence of death may be granted in all cases.

5. Sentence of death shall not be imposed for crimes committed by persons below eighteen years of age and shall not be carried out on pregnant women.

Regional human rights treaties contain additional limitations. For instance, Article 4(4) of the American Convention on Human Rights provides that the death penalty shall not be imposed for 'political offenses or related common crimes.9 Article 4(5) of the American Convention imposes an upper age limit as well, prohibiting the execution of individuals who were over the age of seventy at the time of the crime. ${ }^{10}$ The African Charter on Human and People's Rights provides merely that individuals may not be arbitrarily deprived of their right to life, without mentioning capital punishment. ${ }^{11}$ Although at the time of its adoption in 1950 the European Convention on Human Rights set forth no meaningful limitations on the application of the death penalty, ${ }^{12}$ the adoption of Protocols 6 and 13 to the European Convention have largely superseded its text by bringing about near total abolition in Europe. ${ }^{13}$

The limits on the application of the death penalty provided by Article 6 of the ICCPR were expanded in ECOSOC's Safeguards Guaranteeing Protection of the Rights of Those Facing the Death Penalty ('Safeguards'). ${ }^{14}$ Although the Safeguards were adopted by resolution and lack the binding force of a treaty, they may nonetheless, as Professor Schabas has argued, embody norms of customary law. ${ }^{15}$ The Safeguards added to the categories of individuals who may not be subjected to the death penalty, providing that capital punishment may not be imposed on 'persons who have become insane. The Safeguards likewise set forth additional procedural safeguards for death penalty trials. They established a minimal burden of proof in capital cases ${ }^{16}$ and stated that no death sentence may be imposed in the absence of

9. American Convention on Human Rights (adopted 22 November 1969, entered into force 18 July 1978) 1144 UNTS 123, OAS Treaty Series No. 36, reprinted in Basic Documents Pertaining to Human Rights in the Inter-American System, OEA/SerLV/II.82 Doc 6 Rev 1 at 25 (1992) art. 4(4).

10. Ibid art. 4(5).

11. African (Banjul) Charter on Human and People's Rights (adopted 27 June 1981, entered into force 21 October 1986) (1982) 21 ILM 58.

12. See Convention for the Protection of Human Rights and Fundamental Freedoms (European Convention on Human Rights, as amended) [hereinafter ECHR] art. 2.

13. European Convention on Human Rights Protocols 6 and 13.

14. ECOSOC 'Safeguards Guaranteeing Protection of the Rights of Those Facing the Death Penalty’ Res 1984/50 (25 May 1984) [hereinafter Safeguards].

15. William Schabas, 'International Norms on Execution of the Insane and the Mentally Retarded' (1993) 4(1) Crim L Forum 95, 101.

16. Safeguards (n 14). ('Capital punishment may be imposed only when the guilt of the person charged is based upon clear and convincing evidence leaving no room for an alternative explanation of the facts'). 
fair trial guarantees and adequate legal representation. ${ }^{17}$ They established the right to appeal ${ }^{18}$ and provided that no death sentence may be carried out 'pending any appeal or other recourse procedure. Finally, the Safeguards addressed the method of execution for the first time, providing that 'Where capital punishment occurs, it shall be carried out so as to inflict the minimum possible suffering.'

The texts mentioned above have been supplemented by the jurisprudence of both international and national tribunals. Litigation before those courts has resulted in a solid body of jurisprudence limiting how-and to whom - the death penalty can lawfully be applied. In this regard, decisions regarding the inhumanity of lengthy incarceration on death row, also known as 'death row phenomenon', are noteworthy, ${ }^{19}$ as is the increasing number of jurisdictions that have rejected the mandatory death penalty. ${ }^{20}$ But the capacity of international law to transform state practice is limited in several respects that are all too familiar to human rights advocates.

\section{THE LIMITATIONS OF INTERNATIONAL LAW}

International law's lack of an adequate enforcement mechanism means that powerful states can readily ignore even binding international norms without meaningful repercussions. Weak states can likewise evade their international responsibilities by invoking their lack of resources or human capacity. International law itself often provides insufficient guidance to even those states that are well intentioned, setting out vague standards with little attention as to how those standards should be implemented in practice. As a result of these factors, there is a significant gap between existing international norms and state practice regarding the death penalty.

\section{A. Defiance by Powerful States}

The lack of an enforcement mechanism has always been the Achilles heel of the international legal regime. Compliance with international law is motivated by a

17. Ibid. ('Capital punishment may only be carried out pursuant to a final judgement rendered by a competent court after a legal process which gives all possible safeguards to ensure a fair trial, at least equal to those contained in article 14 of the International Covenant on Civil and Political Rights, including the right of anyone suspected of or charged with a crime for which capital punishment may be imposed to adequate legal assistance at all stages of the proceedings').

18. Ibid. ('Anyone sentenced to death shall have the right to appeal to a court of higher jurisdiction, and steps should be taken to ensure that such appeals shall become mandatory').

19. See eg Vatheeswaran $v$ State of Tamil Nadu, 2 SCR 348, 353 (India 1983); Soering $v$ United Kingdom App no. 14038/88 (ECtHR, 7 July 1989); Pratt and Morgan $v$ The Attorney General of Jamaica, 2 AC 1, 4 All ER 769 (Privy Council 1993) (en banc); Catholic Commin for Justice \& Peace in Zimbabwe v Attorney General, No. SC 73/93 (Zimb 24 June 1993) 14 Hum Rts LJ 323 (1993).

20. See Spence and Hughes $v$ The Queen, Crim Apps Nos. 20/1998 and 14/1997 (2 April 2001) (E Carib Ct Apps) (St. Vincent \& the Grenadines et St. Lucia); Kafantayeni et al. v Attorney General, (2007) MWHC 1 (Malawi); Reyes $v$ The Queen (2002) 2 App Cas 235 (PC) (Belize); The Queen $v$ Hughes (2002) 2 App Cas 259 (PC) (St. Lucia); Fox v The Queen (2002) 2 App Cas 284 (PC) (St. Kitts \& Nevis); Watson v The Queen (2004) UKPC 34 (Jamaica); Bowe and Davis $v$ The Queen 
complex array of factors, including the prospect of reciprocal concessions by other states and pressure from multinational institutions, governmental actors, and nongovernmental organizations. These relatively weak mechanisms work best with states that are either heavily invested in the maintenance of an intergovernmental regime (as is the case for many European countries) or those that are, at least to a certain extent, economically or politically dependent on foreign states and/or international institutions. Powerful states such as China and the United States, however, are highly resistant to international pressure, and face few significant repercussions when they ignore their international commitments.

Perhaps the clearest example of international law's limitations in this regard is the United States' failure to comply with the judgment of the International Court of Justice (ICJ) in Avena and Other Mexican Nationals. ${ }^{21}$ In 2003, Mexico brought suit against the United States on behalf of fifty-two Mexican nationals who had been sentenced to death in the United States, alleging that they were entitled to a remedy for the United States' failure to advise them of their rights to consular notification and access under Article 36 of the Vienna Convention on Consular Relations (VCCR). ${ }^{22}$ Invoking the Optional Protocol to the VCCR, ${ }^{23}$ Mexico asked the ICJ to annul the death sentences and convictions of each of the Mexican nationals who had been sentenced to death. The United States argued that Article 36 did not give rise to any individual right to a judicial remedy, and suggested that the clemency process was best suited to address the violations in question. ${ }^{24}$

In its March 2004 judgment, the ICJ found that the United States had violated the consular rights of fifty-one Mexican nationals and held that they were entitled to a judicial remedy for those violations. Nevertheless, the ICJ refused to annul the convictions and sentences as requested by Mexico, finding instead that each Mexican national was entitled to judicial review and reconsideration of his conviction and sentence to ascertain whether, and how, he was prejudiced by the violation of his Article 36 rights. ${ }^{25}$ In essence, the remedy ordered by the ICJ was procedural in

(2006) 1 WLR 1623, 1639 (Bahamas); Attorney General v Kigula, Crim App No. 3/ 2006 (Sup Ct of Uganda, 21 January 2009); Mutiso v Republic, Crim App No. 17/2008 (Ct of Appeal of Kenya, 30 July 2010) 33-36.

21. Avena and Other Mexican Nationals (Mexico v. US) (Merits) ICJ Rep 12 (2004) [hereinafter Avena Judgment].

22. Vienna Convention on Consular Relations (adopted 24 April 1963, entered into force 19 March 1967) 21 UST 77, 313, 369 [hereinafter Vienna Convention].

23. Optional Protocol Concerning the Compulsory Settlement of Disputes to the Vienna Convention (adopted 24 April 1963, entered into force 19 March 1967) 21 UST 325 [hereinafter Optional Protocol].

24. The Avena proceedings followed on the heels of a similar dispute in LaGrand (FRG v. US) (Merits) ICJ Rep 466 (2001). LaGrand involved the case of two German brothers who had been sentenced to death in Arizona in the absence of consular notification and access under Article 36 of the Vienna Convention. In its judgment on the merits, the ICJ found that the United States had breached its obligations to Germany and the LaGrand brothers by failing to provide review and reconsideration of their convictions and sentences in light of the Vienna Convention violations.

25. Avena Judgment (n 21) 70-73. 
nature: it required, at a minimum, that the courts examine the nature of the violation and its effects on the capital prosecution of each Mexican national.

Approximately one year after the ICJ's decision was issued, former president George W. Bush issued a memorandum to the attorney general of the United States in which he directed state courts to comply with the ICJ's decision by providing the required judicial review and reconsideration. Texas immediately contested the president's power to enforce the ICJ's judgment. The dispute eventually reached the United States Supreme Court in the case of Medellin v. Texas, ${ }^{26}$ in which the Court decided that the president lacked the power to compel state compliance with the ICJ ruling. Although the Court acknowledged that the ICJ judgment was binding as a matter of international law, it held that it was non-self-executing. On that basis, the Court essentially determined that only Congress held the power to enforce the judgment at a national level. ${ }^{27}$

Since the Medellin judgment was issued in 2008, four Mexican nationals have been executed without receiving the review and reconsideration mandated by Avena. ${ }^{28}$ In each case, the United States Supreme Court declined to revisit its decision in Medellin and refused to issue stays of execution. Meanwhile, both the US Senate and the House of Representatives have considered legislation to implement the Avena judgment, but the opposition of key Republican leaders has doomed all efforts to ensure its passage. The legal landscape is not entirely bleak: the Supreme Courts of Nevada and Oklahoma have ordered judicial hearings in accordance with Avena, ${ }^{29}$ and one Mexican national's death sentence was subsequently commuted to life imprisonment. ${ }^{30}$ But in each of those two states, there is only one Mexican national affected by the ICJ's judgment. The vast majority of Mexican nationals named in the ruling are incarcerated in either Texas or California, where the courts have thus far refused to provide the required review and reconsideration.

Under Article 94 of the UN Charter, if any state fails to comply with an ICJ judgment in a case in which it is a party, the other party may seek the intervention of the Security Council. The Security Council's powers to compel enforcement of the judgment are somewhat vague: it may make 'make recommendations' or 'decide upon measures to be taken' to give effect to the judgment. ${ }^{31}$ In March 2014, Mexico addressed a letter to the president of the Security Council:

[R] eiterat[ing] its indignation at the execution of Mexican citizens in violation of the ICJ ruling and emphasiz[ing] its concern regarding the negative

26. Medellin v Texas 552 US 491, 499 (2008).

27. Although the Court did not rule out 'other means' of enforcing the judgment, it failed to identify any other measures that would not require congressional approval.

28. José Ernesto Medellín Rojas, Humberto Leal García, Edgar Tamayo Arias, and Ramiro Hernández Llanas.

29. See Gutierrez v State, No. 53506 Order of Remand and Reversal (Nev 2012); Torres v Oklahoma No. PCD-04-442 (Okla Crim App 2004).

30. See Torres v State 120 P 3d 1184 (Okla Crim App 2005).

31. UN Charter (adopted 26 June 1945, entered into force October 24, 1945) 59 Stat 1031, TS 993, 3 Bevans 1153. 
impact of this situation on the international consular assistance and protection regime. ${ }^{32}$

But the letter stopped short of demanding action by the Security Council pursuant to Article 94.

As of September 2017, with the Republican Party dominating both chambers of Congress and a Republican president in the White House, there is little chance that implementing legislation will be passed in the near future. The United States is in clear violation of its international legal obligations, yet the international community appears powerless-or unwilling - to take further measures to compel compliance. In its December 2014 resolution calling for a moratorium on the death penalty, the UN General Assembly for the first time called upon states to respect their obligations under Article 36 in capital cases. ${ }^{33}$ Predictably, the United States abstained from the resolution.

It is difficult to imagine that policymakers and judges in a smaller, less powerful country would react with the same indifference to the judgment of the world's highest tribunal. Indeed, the highest courts of both Mexico and Germany have adhered to the ICJ's judgements in LaGrand and Avena, even though they were the victors in each lawsuit. ${ }^{34}$ The United States may increasingly be viewed as an international pariah with respect to its execution of foreign nationals, but these reputational consequences have failed to bring about any meaningful change at a national level.

\section{B. Negligence by Weak States}

Retentionist states located in the global South sometimes display the same indifference-or outright hostility-to international law that the above example illustrates: North Korea comes to mind. But many states with weak economies and dysfunctional legal institutions simply lack the financial resources and human capacity to implement the Safeguards and other international norms regarding the application of the death penalty. Theirs is a passive defiance: rather than openly rejecting international norms, they justify their failure to apply them by invoking the very real budgetary constraints that impede access to justice.

To take just one example, international law requires that individuals accused of capital crimes be provided with legal counsel. It is not enough simply to appoint a lawyer on the day of trial; rather, under Article 14 (3)(b) of the International Covenant on Civil and Political Rights, counsel must have adequate time and facilities to prepare for trial. In addition, states must take measures to ensure that counsel is minimally qualified and competent to represent the accused..$^{35}$ The Safeguards set forth 'the right of anyone suspected of or charged with a crime for which capital

32. Secretaría de Relaciones Exteriores, 'Mexico Condemns the Execution in Texas of Its Citizen Ramiro Hernández Llanas', Press Release No. 140, April 9, 2014.

33. UNGA Res 69/186 (18 December 2014).

34. See Amparo Directo en Revisión 517/2011 Florence Marie Cassez Crepin, (Pleno de la Suprema Corte de Justicia 2013) (Mexico); Bundesverfassungsgericht [BVerfG] (2013) 2 BvR 1579/11, paras. 11-12 (F.R.G.).

35. See Artico v Italy App no. 6694/74 (ECtHR, 13 May 1980) para. 33. See also Human Rights Committee, General Comment 32, Article 14: Right to equality before courts and tribunals and 
punishment may be imposed to adequate legal assistance at all stages of the proceedings'. And in its 1989 resolution on the implementation of the Safeguards, ECOSOC made clear that states have an obligation to:

$[\mathrm{P}]$ rovide special protection to persons facing charges for which the death penalty is provided by allowing time and facilities for the preparation of their defence, including the adequate assistance of counsel at every stage of the proceedings, above and beyond the protection afforded in non-capital cases. ${ }^{36}$

This rule is largely neglected in many states. In South Sudan, prisoners have been convicted and sentenced to death with no legal representation whatsoever. ${ }^{37}$ Severe shortages of lawyers have been reported in Afghanistan, Guinea, Malawi, Chad, Benin, Burkina Faso, Malawi, Mali, Sierra Leone, Republic of Congo, Eritrea, Gambia, South Sudan, Sudan, and Tanzania. ${ }^{38}$ Even where lawyers are available, they are often inexperienced and ill-prepared to defend an individual facing capital charges. ${ }^{39}$ In Equatorial Guinea, Guinea, Malawi, Uganda, and Zimbabwe, defense attorneys sometimes meet their clients for the first time on the day of trial. ${ }^{40}$

Many of these states have enacted legislation providing that indigent defendants facing capital trials are entitled to the assistance of a legal aid lawyer. In practice, however, 'state budget allocations to legal aid are minimal. ${ }^{\text {'1 }}$ In Sierra Leone, lawyers

to a fair trial, UN Doc CCPR/C/GC/32 (July 2007) (noting that it is 'axiomatic' that the accused in a capital case be provided effective legal representation, and detailing the circumstances under which a state bears responsibility for ensuring a minimum level of competence).

36. ECOSOC Res 1989/64 'Implementation of the safeguards guaranteeing protection of the rights of those facing the death penalty' (24 May 1989).

37. See Human Rights Watch 'South Sudan: Place Moratorium on Death Penalty' (2012) www. hrw.org/news/2012/11/04/south-sudan-place-moratorium-death-penalty (last accessed 19 February 2015).

38. See Death Penalty Worldwide, www.deathpenaltyworldwide.org/country-search-post.cfm?980chk $=$ on, (last accessed 30 January 2015).

39. See International Federation for Human Rights \& The Botswana Centre for Human Rights, 'The Death Penalty in Botswana Hasty and Secretive Hangings: International Fact-Finding Mission' No. 473/2 (2007) 21; Amnesty International, 'Nigeria: Waiting for the Hangman' AFR 44/020/2008 (2008) 17; International Federation for Human Rights, 'The Death Penalty in Thailand', No. 411/2 (2005).

40. Amnesty International, 'Equatorial Guinea: Submission to the UN Universal Periodic Review' AFR 24/002/2009 (2009); Human Rights Watch, 'We Have Lived in Darkness: A Human Rights Agenda for Guinea's New Government' (2011), www.hrw.org/reports/2011/05/24/we-have-liveddarkness-0 (last accessed 19 February 2015); Graeme L. Hall, 'Death Row in Uganda', Counsel Magazine (2012), www.doughtystreet.co.uk/documents/uploaded-documents/Counsel_2012_ 08_Int_Hall_(Final).pdf (last accessed 19 February 2015); Death Penalty Worldwide, 'Malawi', www.deathpenaltyworldwide.org/country-search-post.cfm?98-0chk=on (last accessed 30 January 2015); Brian Hungwe, 'On Zimbabwe's Death Row without a Lawyer' BBC News (2 May 2010), http://news.bbc.co.uk/2/hi/8675062.stm (last accessed 19 February 2015).

41. United Nations Office on Drugs and Crime, 'Access to Legal Aid in Criminal Justice Systems in Africa' (2011) vii. 
receive US\$150 to represent the accused in capital cases. ${ }^{42}$ The UN Office on Drugs and Crime reported in 2011 that governments typically allocated few resources to legal aid. ${ }^{43}$ Governmental neglect in the provision of legal aid to indigent defendants has dire consequences in capital cases, and should lead to a suspension of death penalty trials. Article 6 (2) of the ICCPR makes clear that where the provisions of the Covenant are not respected, the death penalty may not be carried out. ${ }^{44}$ But courts continue to sentence individuals to death, even where the performance of defense counsel falls far below minimally acceptable levels.

Another example of how weak states have evaded compliance with legal norms is found in Malawi, where the legal system struggled for years to implement a seminal 2007 decision regarding the application of the death penalty. In 2007, the High Court of Malawi found the mandatory death penalty for murder to be unconstitutional in Kafantayeni and Others v. Attorney General, ${ }^{45}$ citing foreign and international jurisprudence to support its conclusion that the mandatory death penalty violated the offender's rights to a fair trial, to have access to the courts, and to be protected from inhuman treatment or punishment. The High Court determined that each of the plaintiffs was entitled to be resentenced, after being given an opportunity to present evidence pertaining to 'the individual offender and the circumstances of the offense. ${ }^{46}$ In Jacob v. The Republic, the Supreme Court of Appeal affirmed this principle, agreeing 'that offenses of murder differ, and will always differ, so greatly from each other that we think it is wrong and unjust that they should attract the same penalty or punishment. ${ }^{47}$

In Yasini v. The Republic, the Supreme Court made clear that all prisoners who had received mandatory death sentences were entitled to be resentenced. ${ }^{48}$ The court further noted that it was the responsibility of the Director of Public Prosecutions (DPP) to present each case for rehearing. ${ }^{49}$ But despite this directive, neither Legal Aid nor the DPP sought resentencing hearings for the approximately 192 prisoners who had been given mandatory death sentences prior to the Kafantayeni judgment. ${ }^{50}$ As of

\section{Ibid 11.}

43. Ibid 18-19.

44. ICCPR art. 6(2) ('sentence of death may be imposed only for the most serious crimes in accordance with the law in force at the time of the commission of the crime and not contrary to the provisions of the present Covenant').

45. Kafantayeni et al. (n 20).

46. Ibid 11.

47. MSCA Crim App No. 18/2006, Sup Ct of App at Blantyre (Jacob).

48. MSCA Crim App No. 29/2005, Sup Ct of App at Blantyre 11-12.

49. Ibid.

50. Most of these prisoners have had their death sentences commuted to life imprisonment, but are still entitled to resentencing because, under a discretionary sentencing regime, they could have received a term of years. See Sandra Babcock and Ellen Wight McLaughlin, 'Reconciling Human Rights and the Application of the Death Penalty in Malawi: The Unfulfilled Promise of Kafantayeni v. Attorney General' in Peter Hodgkinson (ed), Capital Punishment: New Perspectives (Surrey: Ashgate 2013). 
January 1, 2015, only one prisoner had been resentenced-Mr. Kafantayeni himself. In the meantime, ten individuals had died in prison.

There are myriad reasons why Malawi's justice system was slow to conduct resentencing hearings in the wake of Kafantayeni. As Ellen Wight McLaughlin and I have detailed elsewhere, ${ }^{51}$ Malawi has long struggled to clear a backlog of homicide trials, leading to severe prison overcrowding. The Legal Aid department is perpetually short-staffed and under-resourced, ${ }^{52}$ and pays little attention to the plight of prisoners once they are convicted and sentenced to death. Case files are routinely lost: after an eight-month search for the case files of the 192 prisoners given mandatory death sentences, only 86 files were located. Appellate judgements were found in only twenty-three cases, indicating that the great majority of prisoners sentenced to death in Malawi never receive any appellate review of their convictions and death sentences. Judicial inertia and labour conflicts have also played a role. The Supreme Court refrained from giving express guidance to High Court judges regarding the procedures to be followed during the resentencing hearings, resulting in confusion about precisely how they should be handled. Nevertheless, in October 2014, the judiciary announced that it would soon commence with resentencing hearings pursuant to Kafantayeni. Shortly thereafter, the judiciary support staff went on strike for two months. Court cases came to a standstill. Once the strike was over, the courts had to clear the backlog of matters that hadn't been heard due to the strike, resulting in further delay for the Kafantayeni petitioners.

The slow progress toward implementation of the Kafantayeni judgment illustrates the danger in over-reliance on legal victories to measure a nation's progress towards full compliance with legal rights. Judicial decisions announcing new limitations on the application of the death penalty should be celebrated, but in the absence of sustained engagement to ensure their implementation, the celebration may be premature.

\section{Ignorance by Well-Intentioned States}

A third barrier to the implementation of international norms in capital cases derives from the lack of data regarding death penalty practices. Many retentionist governments claim to be in compliance with their obligation to protect certain categories of offenders from the application of the death penalty. The absence of empirical research, combined with government secrecy about death penalty practices, makes it difficult to verify these claims. Yet abolitionist governments, intergovernmental organizations, and international non-governmental organizations (INGOs) often accept them uncritically.

By way of illustration, most states claim to be in compliance with their international obligation to exempt juvenile offenders from capital punishment. ${ }^{53}$ But

\section{Ibid.}

\section{Ibid.}

53. See Report of the Secretary-General 'Capital punishment and implementation of the safeguards guaranteeing protection of the rights of those facing the death penalty' (13 April 2015) UN Doc E/2015/49, para. 78 ('All of the reporting States that retain the death penalty indicated that they do not allow the execution of persons for crimes committed by persons below 18 years of age'). 
many of those same states have no national birth registry, ${ }^{54}$ and determining the age of a criminal suspect is often a matter of guesswork. This phenomenon is rarely discussed in the abolitionist community, and only a few cases have been publicized..$^{55}$ Indeed, international observers regularly claim that only a tiny handful of states continue to execute juvenile offenders. Preliminary research, however, indicates that the sentencing of juvenile offenders is far more widespread than is commonly believed. ${ }^{56}$

Another example relates to the implementation of international norms prohibiting the execution of individuals with severe mental illnesses or intellectual disabilities. In 2002, the European Union filed an amicus curiae brief before the United States Supreme Court in support of Ernest McCarver, an intellectually disabled man facing execution in Virginia. The EU argued that the United States was 'one of the last countries in the world' that continued to execute individuals with mental retardation, ${ }^{57}$ and urged the Supreme Court to strike down the practice. The Supreme Court ultimately cited the EU brief in its decision finding that the execution of individuals with mental retardation amounted to cruel and unusual punishment in violation of the Eighth Amendment to the US Constitution. ${ }^{58}$

Although no treaty expressly prohibits the execution of individuals with severe mental illnesses or intellectual disabilities, these norms are widely accepted. As noted above, the Safeguards provide that the death penalty shall not be carried out 'on persons who have become insane. In 1989, in a resolution regarding the implementation of the Safeguards, the Economic and Social Council urged states to eliminate the death penalty 'for persons suffering from mental retardation or extremely limited mental competence, whether at the stage of sentence or execution. ${ }^{59}$ In subsequent resolutions urging full compliance with the Safeguards, the United Nations Human Rights Commission repeatedly called upon states 'Not to impose the death penalty on a person suffering from any form of mental disorder or to execute any such person.60

In 1993, Professor Schabas concluded that the prohibition on the execution of the insane had attained the status of customary international law. ${ }^{61}$ At that time,

54. UNICEF notes that 70 percent of all births in sub-Saharan Africa, and 63 percent of all births in South Asia, went unregistered in 2000. 'Factsheet: Birth Registration', UNICEF, www.unicef. org/newsline/2003/03fsbirthregistration.htm (last accessed 13 December 2015).

55. See 'Minor's Death Penalty Set Aside', The Times of India, 26 November 2011. The UN Secretary-General briefly mentioned the problem in his 2015 report on the death penalty. See Report of the Secretary-General (n 53) para. 79.

56. In Malawi, preliminary research conducted by the author indicates that at least 20 out of roughly 200 persons sentenced to death since 1994 may have been juveniles at the time of the crime for which they were sentenced to death. There is every reason to believe that these results would be replicated in other sub-Saharan African countries that lack a functioning birth registry.

57. Brief of the European Union as Amicus Curiae, McCarver v. North Carolina, 533 US 975 (2001).

58. Atkins v Virginia 536 US 304, 316 (2002).

59. ECOSOC 'Implementation of the Safeguards Guaranteeing Protection of the Rights of Those Facing the Death Penalty' Res 1989/64 (24 May 1989).

60. See eg UNCHR Res 67 (2003) UN Doc E/CN.4/RES/2003/67.

61. Schabas (n 15) 114. 
however, the prohibition on the execution of individuals with intellectual disabilities was not as widely embraced: in the United States, the Supreme Court did not abolish the practice until its 2002 decision in Atkins v. Virginia. ${ }^{62}$

As with the execution of the insane, there is no empirical evidence to indicate that states willfully execute individuals with intellectual disabilities. At the same time, however, there is little empirical data to prove that states consciously refrain from carrying out such executions. Although most provide that offenders who suffer from severe forms of mental illness cannot be held criminally responsible for their actions, only a handful of countries have adopted legislation or regulations to ensure that people with intellectual disabilities, or those who become severely mentally ill after their death sentence is imposed, will be spared execution. ${ }^{63}$ Professor Schabas has insisted 'the absence of legislation is not a reliable indicator of state practice, since many states de facto either limit or abolish the death penalty'.64 Yet in practice, many retentionist states have failed to implement measures sufficient to ascertain whether prisoners facing the death penalty suffer from mental impairments that would warrant commutation of their sentences. ${ }^{65}$ As the UN Secretary-General noted in his 2009 report on the implementation of the third Safeguard:

The real difficulty with the safeguard lies not in its formal recognition but in its implementation. Whereas with juvenile offenders or pregnant women, the determination that a person belongs to the protected category is relatively straightforward, there is an enormous degree of subjectivity involved when assessing such concepts as insanity, limited mental competence and 'any form of mental disorder'. The expression 'any form of mental disorder' probably applies to a large number of people sentenced to death. ${ }^{66}$

One of the problems is definitional. Many countries do not distinguish between mental illness and intellectual disability, even though these are distinct forms of mental impairments. A decade ago, the UN Secretary-General recommended 'clarifying the safeguards to be applied to the mentally ill as opposed to the insane or the mentally retarded', after noting that the application of these prohibitions was

\section{Atkins (n 58).}

63. Death Penalty Worldwide, 'Mental Retardation', www.deathpenaltyworldwide.org/mentalretardation.cfm (last accessed 27 January 2015).

64. Schabas (n 15) 111.

65. In 2005, the UN Secretary-General noted that '[e]ven though most responding countries state that the insane and the mentally retarded are shielded from the infliction of the death penalty and especially from execution, reports of mentally ill and retarded persons facing the death penalty have continued to emerge during the five years covered by the seventh survey'. ECOSOC Report of the Secretary-General, 'Capital punishment and implementation of the safeguards guaranteeing protection of the rights of those facing the death penalty' (2005) UN Doc E/2005/ 3 (88).

66. ECOSOC 'Report of the Secretary-General: Capital punishment and implementation of the safeguards guaranteeing protection of the rights of those facing the death penalty' (2009) UN Doc E/2010/10. 
clouded by competing interpretations. ${ }^{67}$ Hood and Hoyle echoed these concerns in 2008, when they noted that it was impossible 'to gauge the extent to which the widespread prohibition on the execution of the mentally retarded has in fact provided a safeguard for all those to whom it might apply in principle. ${ }^{68}$ In the years since, little progress has been made to ensure that individuals with severe mental impairments are protected from execution.

As noted above, many states have enacted legislation providing that an individual may not be convicted if he could not appreciate the nature or wrongfulness of his actions at the time of the offense (the so-called 'insanity defense'). Likewise, most states provide that a suspect may not be prosecuted if he cannot understand the character or consequences of his legal proceedings (known as lack of 'fitness' or 'competence' to stand trial). But such provisions fail adequately to protect from execution individuals with mental disorders. As an initial matter, mentally impaired individuals often do not meet the definitions of 'insanity' or 'incompetence.' In Nigeria, for example, the Criminal Code Act stipulates that an individual is excluded from criminal liability if at the time of the crime he or she is in 'such a state of mental disease ... as to deprive him of capacity to understand what he is doing, or of capacity to control his actions, or of capacity to know not do the act.'.9 ${ }^{69}$ The Act simultaneously provides, however, that those who are deluded can be criminally responsible as long as their delusions aren't related to the crime for which they are convicted. ${ }^{70}$ In other words, an individual could be completely delusional as a result of his mental illness, and still be lawfully sentenced to death. Similarly, Chinese law provides that no criminal responsibility attaches to a 'mental patient' if he 'causes harmful consequences at a time when he is unable to recognize or control his own conduct.' However, a mental patient 'whose mental illness is of an intermittent nature shall bear criminal responsibility if he commits a crime when he is in a normal mental state. ${ }^{71}$

Moreover, statutory provisions that focus on the offender's mental status at the time of the crime elide the distinction between the offender's guilt (where the insanity test is particularly relevant) and the penalty that should be imposed as a consequence of his actions. In determination of the latter, courts should take into account mental impairments that affect an individual's judgment, perceptions, and behavior-regardless of whether those impairments prevented him from understanding that his actions were wrong. As Justice Stevens explained in the seminal case of Atkins v. Virginia:

Mentally retarded persons frequently know the difference between right and wrong and are competent to stand trial. Because of their impairments, however, by definition they have diminished capacities to understand and process

67. UNSG Report 2005 (n 65).

68. Roger Hood and Carolyn Hoyle, The Death Penalty: A Worldwide Perspective 4th edn (New York: Oxford University Press 2008) 198.

69. Nigeria Criminal Code Act, Laws of the Federation of Nigeria Ed. 2000 Ch. 77 (as amended to 31 December 2000) art. 28.

70. Ibid.

71. Criminal Law of the People's Republic of China (as amended to 25 February 2011) art. 18. 
information, to communicate, to abstract from mistakes and learn from experience, to engage in logical reasoning, to control impulses, and to understand the reactions of others.... Their deficiencies do not warrant an exemption from criminal sanctions, but they do diminish their personal culpability. ${ }^{72}$

Another shortcoming of existing legislative provisions that focus exclusively on insanity or incompetence is their failure to address the situation of prisoners who develop mental illnesses after sentencing. Insanity and incompetence to stand trial are concepts that relate only to an individual's functioning at the time of the crime (insanity) and at the time of trial (incompetence). But many prisoners develop severe mental illnesses only after they are convicted and sentenced to death. ${ }^{73}$ The view that they should be protected from execution is related to long-held beliefs that it is unjust to execute someone who cannot fully comprehend the nature of his punishment. ${ }^{74}$ Here again, most states do not trumpet their right to execute severely mentally ill prisoners-and if asked whether they do so as a matter of course, would be inclined to deny it. As Professor Schabas has noted, 'virtually all societies refuse to execute an insane person. ${ }^{75}$ Nevertheless, in the absence of legislation or local rules requiring regular mental health assessments of condemned prisoners, there is no guarantee that their mental health will be taken into account at the time their sentences are carried out. A review of the legislation of eighty-seven retentionist states and territories reveals that only fifteen have adopted legislative provisions expressly designed to prevent the execution of prisoners who have become mentally ill while awaiting execution. ${ }^{76}$

Adoption of appropriate legislation or administrative regulations could provide useful guidelines to both courts and prison officials regarding the need to protect this

\section{Atkins (n 58) (citations omitted).}

\section{The UN Secretary-General concurs:}

This issue [the prohibition of the death penalty for people 'who have become insane'] is often confused with the related but different questions of responsibility for the crime itself and application of an insanity defence, and of fitness to stand trial, where a person is unable to participate in the trial for mental health reasons. The norm protecting insane and mentally disabled persons from execution applies even when there is no question of competency at the time the crime was committed or at trial. It is not uncommon for a person to become insane subsequent to conviction and sentence of death, and in such cases execution is forbidden by the third safeguard.

UNSG Report 2009 (n 66), para. 91.

74. See Ford $v$ Wainwright, 477 US 399, 409-10, 417 (1986) ('the natural abhorrence civilized societies feel at killing one who has no capacity to come to grips with his own conscience or deity is still vivid today').

75. Ibid 96, 112-13.

76. This review was conducted by searching the database maintained by Cornell Law School's Death Penalty Worldwide, which tracks legislation in eighty-seven retentionist states and territories, including legislation regarding the application of the death penalty to individuals with mental or intellectual disabilities. See Death Penalty Worldwide, www.deathpenaltyworldwide. org (last accessed 16 February 2015). 
vulnerable population from the application of the death penalty. But that alone may not suffice to ensure that such individuals are not subjected to capital punishment. Even were they to adopt appropriate definitions and protocols, many retentionist states have limited capacity to provide reliable mental health assessments of individuals condemned to death. The Privy Council has repeatedly decried the shortage of qualified forensic psychiatrists in the Commonwealth Caribbean to conduct such assessments. ${ }^{77}$ As a result, lawyers engaged in litigation before the appellate courts frequently employ British psychiatrists to conduct mental health assessments. In Malawi, as of January 2015 there was not a single qualified Malawian psychiatrist in the entire country; forensic mental status evaluations are typically carried out by 'clinical officers' or psychiatric nurses who are neither psychiatrists nor psychologists, but who have had some clinical training. ${ }^{78}$ Mental health providers are scarce in other sub-Saharan African countries as well. ${ }^{79}$ Those who exist are already overburdened, and if they are not given the training, time, and resources to conduct competent mental health assessments, it is difficult to see how they can ensure that prisoners with severe mental impairments are spared from execution.

These challenges highlight the complexity of ensuring compliance even with international norms that enjoy a high degree of acceptance. There is no reason to doubt that most states (most of the time) do not intentionally execute individuals with severe mental illnesses or mental retardation. Nevertheless, the international community should not uncritically accept the assertions of states who claim not to execute individuals with mental disorders. In reality, governments have taken insufficient measures to protect such individuals from execution. The international community bears some of the blame for failing to adopt clear definitions and promote best practices in this area. As a result, we simply have no way of knowing how many mentally impaired individuals are executed in any given year.

\section{ADDRESSING THE GAP BETWEEN PRINCIPLE AND PRACTICE}

To increase compliance with international norms restricting the application of the death penalty, abolitionist governments, intergovernmental organizations, and civil society will need to adopt a multipronged approach. First, they must send a clear and consistent message to powerful, intransigent states that their failure to comply with international law is unacceptable. Second, they must form long-term partnerships with government institutions and civil society organizations to promote reform in those states that are willing in theory, but reluctant in practice, to implement international norms regarding the application of the death penalty. Third, they must continue to refine international norms and promote their implementation with due regard to the practical challenges that impede compliance. These measures,

77. UNSG Report 2005 (n 65) para. 88.

78. See Babcock and Wight McLaughlin (n 50).

79. See Atalay Alem, Lars Jacobsson, and Charlotte Hanlon, 'Community-Based Mental Health Care in Africa: Mental Health Workers' Views' (World Psychiatry, 2008), www.ncbi.nlm.nih.gov/ pmc/articles/PMC2327237/ (last accessed 16 February 2015). 
combined with political strategies that increase pressure on retentionist states to abolish capital punishment, will help accelerate global trends towards abolition.

\section{A. Isolating the Powerful States}

When states ignore their international legal obligations, the international community tends to rely on a limited set of tools to induce compliance. Naming and shaming is a time-honored tradition among human rights activists, but powerful governments are not easily swayed by the press releases of non-governmental organizations. Individual governments can take action to show their displeasure with recalcitrant governments-for example, by cancelling high-level visits, reducing aid, or cancelling joint projects-but such measures are often ineffective against powerful states. Moreover, weaker states may be reluctant to take measures that could jeopardize friendly ties with a major trading partner or strategic ally. International and regional human rights bodies can adopt non-binding resolutions, but when the world's most powerful states hold veto power in the Security Council, the possibility of coercive action is limited.

Nevertheless, even powerful states can sometimes be moved by international opprobrium. The United States, in particular, seeks to maintain an image of itself as a law-abiding nation that can be trusted to live up to its commitments. If the international community were to engage in concerted, sustained criticism of the United States' failure to comply with the Avena judgment, it could have an impact on lawmakers' willingness to adopt legislation implementing the judgment, and would certainly increase pressure on the executive branch to prioritize compliance in its dealings with Congress. For such a strategy to be successful, however, nations would need to support resolutions condemning the United States in high-profile fora such as the UN Security Council and the General Assembly. Leaders would need to make public statements criticizing the country's failure to live up to its treaty obligations. And they would need to maintain such pressure over time, even if the United States fails to react.

It is easy to dismiss such a proposition as utopian. But Members of Congress frequently travel abroad and/or meet with foreign congressional delegations. If they are convinced that the United States' violations of its treaty obligations imperil important relationships with foreign nations, they will be more apt to work towards a constructive solution to the current legal impasse. ${ }^{80}$

\section{B. Addressing Implementation Challenges}

Addressing the implementation challenge posed by governments' lack of resources and human capacity seems, at first blush, to be the most straightforward. In short, both governmental and non-governmental donors need to support local efforts to (1) identify practical obstacles to the implementation of international norms, and

80. In a series of meetings the author attended in recent years regarding implementation of the Avena judgment, staff of both Republican and Democratic Members of Congress emphasized repeatedly the importance of sustained pressure from foreign allies on the issue of Avena compliance. 
(2) develop strategies to surmount them. Training is key, but so is sustained international engagement with local actors, including the judiciary, the prosecution, defence counsel, and non-governmental organizations. Therein lies the true challenge. Sustained engagement requires a substantial investment in time and resources, typically over a period of years. International experts and their local partners must be equally committed to a mutually educative, reciprocal process through which they can develop and implement practical measures designed to increase compliance with international standards pertaining to the death penalty.

One example of such an effort relates to the above-mentioned challenges in implementing the Kafantayeni judgment of the Malawi High Court. Since 2009, the international human rights clinics at both Northwestern and Cornell Law Schools have worked with a coalition of stakeholders in Malawi to address the failure to provide resentencing hearings for prisoners given mandatory death sentences. Under my guidance, students and volunteer lawyers interviewed all of the prisoners entitled to resentencing hearings, located available case files, summarized the evidence presented at trial, helped to develop mitigation strategies, and coordinated strategy sessions where stakeholders agreed on the substantive law and procedural framework applicable to the resentencing process. We organized training sessions on the investigation and presentation of mitigation evidence and the relevance of mental health to capital litigation for lawyers, judges, paralegals, and mental health professionals. Most important, we helped build a coalition of local actors who became invested in the resentencing process.

All of these efforts would likely have been for naught, however, had our local partners not obtained a large grant from an international donor to implement their strategic plan. My students and I assisted in the drafting of the grant proposal, which emphasized the need for a collaborative approach involving public and private sectors, and local and international institutions. Malawi's Director of Public Prosecutions; Legal Aid; the Malawi Human Rights Commission; the Malawi Law Society; the Paralegal Advisory Services Institute; the Centre for Human Rights Education, Advice and Assistance; Chancellor College of Law; the INGO Reprieve; and Northwestern and Cornell Law Schools were all named as partners in the grant provided by the Tilitonse Fund. With the Malawi Human Rights Commission playing a coordinating role, each institution was given tasks to fulfil over a series of meetings where decisions were reached by consensus. The coalition met repeatedly with the judiciary, without whose participation the project would have failed entirely.

The first resentencing hearings were held in February 2015. Over the next two and a half years, the judiciary held approximately 150 resentencing hearings. As of this writing, 122 prisoners have been released, and an additional twenty-eight have been given determinate sentences that will lead to their release within the next five to ten years. None were sentenced to death. To conserve resources, all of the resentencing hearings were held in the courthouse closest to the maximum security prison where all the prisoners are held. High Court judges have issued judgments adopting guidelines for capital sentencing proceedings that are broadly consistent with international norms, even though they rarely cite international law. American and South African mental health experts have teamed up with Malawian clinical officers to develop tools to assess the mental health and cognitive functioning of prisoners. The project's success has exceeded the expectations of donors and stakeholders alike, and 
may serve as a model for other African countries transitioning from a mandatory to a discretionary death penalty regime.

The Malawi resentencing project is unique in its collaborative approach, which may not be feasible in all death penalty states. But alternative models of sustained and multi-tiered engagement could be implemented in many other states. Until they are, compliance with international fair trial standards will remain an elusive goal in most capital cases. In the meantime, the message from the international community should be clear and direct: where international fair trial standards cannot be guaranteed, the death penalty may not be imposed.

\section{Refining Existing Norms}

One way to address compliance problems is to provide more explicit guidelines to states regarding the application of international norms. In this regard, it is time for the United Nations to update the Safeguards, which were adopted more than thirty years ago and fail to reflect contemporary norms pertaining to the application of the death penalty.

To take just one example, the Safeguards could be revised to clarify proscriptions against the execution of individuals with severe mental illnesses and intellectual disabilities, as the Secretary-General recommended in $2005 .{ }^{81}$ This is no small challenge, as it is not a simple matter to find definitions capable of universal application. As noted above, cultural differences heavily influence how mental illness and intellectual disabilities are described and defined. Nonetheless, it should be possible to adopt a general definition that is flexible enough to allow for regional differences. What follows is one possible formulation:

States are obligated to prohibit the sentencing to death and execution of those with mental disorders of any kind, including intellectual disabilities and severe mental illnesses, as defined below. In addition, the death penalty may not be carried out on individuals who have developed a severe mental illness or intellectual disability after sentencing but before execution.

Intellectual Disability: A disability characterized by significant limitations in both intellectual and adaptive functioning, as expressed in many everyday social and practical skills.

Severe Mental Illness: A mental disorder that significantly impairs an individual's judgment, perceptions, or behavior during the commission of the offense, subsequent criminal proceedings, or incarceration.

This definition is general enough to be universally applied, but specific enough to provide meaningful guidance for states that are serious about protecting individuals with mental disabilities.

With regard to the right to legal representation, the original Safeguards failed to specify that states have an obligation to appoint legal counsel for the accused in any proceeding that may result in a death sentence, and that the authorities have an ongoing obligation to appoint new counsel or replace existing counsel if he or she fails to provide minimally competent legal assistance. I do not by any means wish 
to suggest that revising the Safeguards will magically transform the quality of legal representation available to those facing the death penalty. But the formulation of reasonably clear principles is a necessary prerequisite to their implementation.

\section{CONCLUSION}

In the 2002 edition of his treatise on capital punishment, Professor Schabas proclaimed, 'The day when abolition of the death penalty becomes a universal norm, entrenched not only by convention but also by custom and qualified as a peremptory rule of jus cogens, is undeniably in the foreseeable future. ${ }^{22}$ Whether Professor Schabas's prediction will become a reality depends on how we define 'foreseeable'. Will we see universal abolition of the death penalty in the next ten years? Certainly not. But abolition by all but a handful of outliers (most likely states that apply a form of sharia law) is conceivable within the next thirty years. Achieving abolition will take concerted effort, time, and resources. Spring has not yet arrived-those piles of snow are still formidable-but a thaw is sure to come. 